\title{
New insights on Br speciation in volcanic glasses and structural controls on
}

\author{
halogens degassing
}

\section{Revision 1}

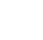

$$
\text { Hazemann }{ }^{5}
$$

${ }^{1}$ Institute for Mineralogy, WWU Muenster, DE48149, Germany

${ }^{2}$ School of Earth Sciences, Bristol University, BS81RJ, Bristol, United-Kingdom

${ }^{3}$ GEOPS, Université Paris Sud, CNRS, Université Paris-Saclay, 91405 Orsay, France

${ }^{4}$ Observatoire des Sciences de l'Univers de Grenoble (OSUG), UMS 832 CNRS, Universite Grenoble Alpes, F-38041 Grenoble, France
${ }^{5}$ Institut Néel, UPR 2940 CNRS, Universite Grenoble Alpes, F-38000 Grenoble, France
*corresponding author (louvel@uni-muenster.de)

ABSTRACT

9

The volcanic degassing of halogen, and especially of the heavier $\mathrm{Br}$ and $\mathrm{I}$, received increased attention over the last 20 years due to their significant effect on atmospheric chemistry, notably the depletion of stratospheric ozone. While the effect of melt composition on halogen diffusion, solubility or fluid-melt partitioning in crustal magma chambers has been thoroughly studied, structural controls on halogen incorporation in silicate melts remain 
poorly known, with only few studies available in simplified borosilicate or haplogranite compositions.

Here, we demonstrate that high-resolution X-ray absorption spectroscopy (HERFDXAS) with a crystal analyser spectrometer (CAS) is well-suited for the study of $\mathrm{Br}$ speciation in natural volcanic glasses which can contain lower $\mathrm{Br}$ concentrations than their laboratory analogs. Especially, HERFD-XAS results in sharper and better-resolved XANES and EXAFS features than previously reported and enables detection limits for EXAFS analysis down to $100 \mathrm{ppm}$ when previous studies required $\mathrm{Br}$ concentrations above the $1000 \mathrm{ppm}$ level. XANES and EXAFS analysis suggest important structural differences between synthetic haplogranite, where $\mathrm{Br}$ is surrounded by $\mathrm{Na}$ and next-nearest oxygen neighbors and natural volcanic glasses of basaltic to rhyodacitic compositions, where $\mathrm{Br}$ is incorporated in at least three distinct sites, surrounded by $\mathrm{Na}, \mathrm{K}$ or $\mathrm{Ca}$. Similar environments, involving both alkali and alkaline earth metals have already been reported for $\mathrm{Cl}$ in Ca-bearing aluminosilicate and our study thus underlines that the association of $\mathrm{Br}$ with divalent cations $\left(\mathrm{Ca}^{2+}\right)$ has been underestimated in the past due to the use of simplified laboratory analogs. Overall, similarities in $\mathrm{Cl}$ and $\mathrm{Br}$ structural environments over a large array of compositions (46-67 wt\% $\mathrm{SiO}_{2}$ ) suggest that melt composition alone may not have a significant effect on halogens degassing and further support the coupled degassing of $\mathrm{Cl}$ and $\mathrm{Br}$ in volcanic systems.

Keywords : halogens, Bromine, magmas, volcanic glasses, speciation, HERFD-XAS 


\section{INTRODUCTION}

Despite their minor concentrations compared to $\mathrm{H}_{2} \mathrm{O}$ and $\mathrm{CO}_{2}$, halogens $(\mathrm{F}, \mathrm{Cl}, \mathrm{Br}$ and I) are critical elements in the evolution of magmatic and volcanic systems, for instance affecting magma rheology and enabling the scavenging and hydrothermal concentration of metals in the crust (Dolejs and Zajacz, 2018; Webster et al., 2018 and references therein). Their release through volcanic degassing has also been demonstrated to affect atmospheric chemistry to different levels, with the rapid transformation of $\mathrm{HBr}$ to reactive $\mathrm{BrO}$ during explosive eruptions triggering ozone depletion at local (within volcanic plume; Bobrowski et al., 2003; Roberts et al., 2009) to global scales (if the plume reaches the stratosphere; Cadoux et al., 2015; Klobas et al., 2017; Kutterolf et al., 2013). Recent improvements in the analytical characterization and detection limits for $\mathrm{F}, \mathrm{Cl}, \mathrm{Br}$ and $\mathrm{I}$ in solid, liquid or gaseous samples (i.e., Cadoux et al., 2017; Lubcke et al., 2014; Roberts et al., 2017; Seo et al., 2011) have also opened new opportunities to use halogen concentrations and elemental ratios $(\mathrm{F} / \mathrm{Cl}, \mathrm{Cl} / \mathrm{Br}$ or $\mathrm{BrO} / \mathrm{SO}_{2}$ ) from volcanic fumaroles, undegassed melt inclusions or degassed lavas as tracers of magma storage conditions, magmatic/hydrothermal activity, or eruption dynamics (BalconeBoissard et al., 2010; Dinger et al., 2018; Lubcke et al., 2014; Seo and Zajacz, 2016). Yet, the effect of decompression on $\mathrm{Br} / \mathrm{S}$ fractionation or the role of mineral sinks such as apatites and sodalites in the volcanic cycling of halogens remain poorly constrained and thus limits the interpretation of these samples.

The accurate interpretation of the deep information carried in melt inclusions or degassing patterns at different volcanic centres requires the development of comprehensive geochemical models that describe the behaviour of different volatiles during fluid exsolution and especially how they partition from magma (melt + crystals) into bubbles or brines (Burgisser et al., 2015). Accordingly, a large number of studies have already been dedicated to $\mathrm{F}$ and $\mathrm{Cl}$. Information on $\mathrm{Br}$ and I are much scarcer, mostly due to the analytical challenge associated with their low concentrations in volcanic glasses (generally $<30 \mathrm{ppm} \mathrm{Br}$ and $<1 \mathrm{ppm} \mathrm{I}$; 
Aiuppa et al., 2009; Bureau et al., 2000-2016; Cadoux et al., 2018; Kutterolf et al., 2013, 2015). Overall, similarities in the ionic radii of $\mathrm{O}$ and $\mathrm{F}$, compare to larger $\mathrm{Cl}, \mathrm{Br}$ and $\mathrm{I}$, have been suggested to account for the larger solubility of $\mathrm{F}$ in silicate melts, and the contrasting preferential partitioning of $\mathrm{Cl}, \mathrm{Br}$ and I towards fluids (Bureau et al., 2000-2016; Dolejs and Zajacz, 2018; Signorelli and Carroll, 2000, 2002; Webster et al., 2018). In silicate melts, both $\mathrm{F}, \mathrm{Cl}$ and $\mathrm{Br}$ solubilities were also found to be at their minimum in metaluminous composition where the aluminium saturation index ASI $\left(\mathrm{Al}_{2} \mathrm{O}_{3} /\left(\mathrm{Na}_{2} \mathrm{O}+\mathrm{K}_{2} \mathrm{O}+\mathrm{CaO}\right)\right)$ is close to 1 . However, while $\mathrm{Cl}$ and $\mathrm{Br}$ solubilities are higher under peralkaline conditions (alkalis> aluminium), $\mathrm{F}$ solubility is higher under peraluminous conditions. Yet, direct constraints on halogens' speciation in melts are extremely scarce, and mostly limited to simplified laboratory analogs, including borosilicates, haplogranite or $\mathrm{CaO}-\mathrm{MgO}-\mathrm{Al}_{2} \mathrm{O}_{3}-\mathrm{SiO}_{2}$ glasses (Cicconi et al., 2019; Evans et al., 2008; McKeown et al., 2011, 2015; Schaller et al., 1992; Stebbins and |Du, 2002). These studies reveal a strong affinity of $\mathrm{Cl}, \mathrm{Br}$ and I for alkalis and alkaline earths-rich environments, with $\mathrm{Cl}$ favouring divalent cations $\left(\mathrm{Ca}^{2+}\right.$ and $\left.\mathrm{Mg}^{2+}\right)$, while $\mathrm{Br}$ and I preferentially bond to monovalent alkalis $(\mathrm{Na}, \mathrm{K})$. On the contrary, $\mathrm{F}$ mostly substitutes for $\mathrm{O}$, forming strong Al-F bonds, and may hence be more efficient in the depolymerisation of aluminosilicate melts (i.e., acting as a network modifier). While these structural controls may lead to the decoupling of halogens from $\mathrm{H}_{2} \mathrm{O}$ and from each other, the speciation of halogens in natural volcanic compositions, such as basalt or andesite, remains unknown up to date, and potentially hinders modelling of halogens fractionation upon magma cooling or degassing. Here, we provide new insights on $\mathrm{Br}$ speciation in silicate glasses of increasingly complex compositions (haplogranite, rhyodacite, andesite and basalts). These are, to the best of our knowledge, the first analyses constraining halogens speciation in natural volcanic compositions. X-ray absorption is a widely used technique to characterize the local structure and chemical state (oxidation state, coordination number, bond distances) of elements in aluminosilicate glasses/melts and crystals of geological interest (Calas et al., 1987; Chalmin et 
al., 2009; Cochain et al., 2015; Farges et al., 2006; Louvel et al., 2013; Wilke, 2018). In the past, an issue with characterization of $\mathrm{Br}$ speciation in silicate glasses/melts has been that

\section{Br K-edge EXAFS data have weak amplitudes, making it difficult to obtain statistically} significant structural parameters from EXAFS fitting. As a consequence, both the study of Cochain et al. (2016) and that of Louvel (2011) show relatively high uncertainties on the coordination number $(\mathrm{N})$ and bond distances $\left(\mathrm{R}_{\mathrm{Br}-\mathrm{O}}\right)$ derived from EXAFS fit for granitic glasses and melts. The weak EXAFS amplitudes are mostly due to large Br-nearest neighbour distances and nearest neighbour positional disorder around Br-sites. One way to overcome this limitation is to use a detection system with a better energy resolution. Especially, 'site-selective' crystal analyser spectrometers (Proux et al., 2017) can be used to improve the signal-to-background ratio and reveal spectral features that were invisible to conventional XANES. This high-energy resolution fluorescence detection (HERFD)-XAS has been successfully applied to better detect absorbing atoms ( $\mathrm{Co}, \mathrm{Br}$, lanthanides) present in different oxidation states or different sites, in metallic oxides, minerals and even hightemperature supercritical fluids (Bordage et al., 2013; Hamalainen et al., 1991; Proux et al., 2017; Vitova et al., 2013). In the present study, HERFD-XAS has been used to investigate $\mathrm{Br}$ speciation in natural volcanic glasses. This approach results in better-resolved XANES features than previously reported, and ultimately enables us to better understand the structural incorporation of $\mathrm{Br}$ in geological melts, even at natural concentration levels $(<300 \mathrm{ppm}$; Aiuppa et al., 2009).

\section{METHODS}

\section{Starting materials and $\mathrm{Br}$ quantitative analyses}

In order to probe the effect of water, $\mathrm{SiO}_{2}$, monovalent alkalis $\left(\mathrm{Na}^{+}, \mathrm{K}^{+}\right)$or divalent alkaline earth $\left(\mathrm{Ca}^{2+}, \mathrm{Mg}^{2+}, \mathrm{Fe}^{2+}\right)$ contents and degree of polymerization, $\mathrm{Br}$ speciation was investigated in 7 different glass compositions, including basalt (B600, B3000), andesite (A10, 
A100), rhyodacite (RD10_Dry, RD500) and haplogranite (Haplo_1wt\%) with 10 to 10,000 ppm $\mathrm{Br}(1 \mathrm{wt} \%)$ and $<0.5$ to $6 \mathrm{wt} \% \mathrm{H}_{2} \mathrm{O}$. Major element compositions, $\mathrm{H}_{2} \mathrm{O}$ and $\mathrm{Br}$ contents are reported in Table 1.

Haplo_1wt $\%$ is a simplified aluminosilicate composition that we use to isolate the structural effects from alkalis $(\mathrm{Na}, \mathrm{K})$ from those from alkaline-earth $(\mathrm{Ca}, \mathrm{Mg})$. It was synthesized from reagent grade powders of $\mathrm{SiO}_{2}, \mathrm{Al}_{2} \mathrm{O}_{3}, \mathrm{Na}_{2} \mathrm{CO}_{3}$ and $\mathrm{K}_{2} \mathrm{CO}_{3}$ that were ground, decarbonized at $800{ }^{\circ} \mathrm{C}$ and later doped with $\sim 1 \mathrm{wt} \% \mathrm{Br}$ introduced as $\mathrm{NaBr}$ powder (SigmaAldrich ${ }^{\circledR}$ ). The powder was loaded with a drop of liquid water in a $\mathrm{Au}_{80} \mathrm{Pd}_{20}$ capsule and heated to $1200{ }^{\circ} \mathrm{C}$ and 1.5 GPa in a piston-cylinder apparatus at ETH Zurich (Louvel, 2011).

All other glasses were prepared from natural volcanic products by Cadoux et al. (2017) to be used as standards for Br contents analysis by Secondary Ion Mass Spectrometry (SIMS) and Laser-Ablation Inductively Coupled Plasma Mass Spectrometry (LA-ICP-MS). The samples consist of basalt, andesite and rhyodacite from Etna and Santorini eruptions that have been crushed, grounded and melted twice at $1400{ }^{\circ} \mathrm{C}$ and $1 \mathrm{~atm}$. The powdered material was then loaded in $\mathrm{Pt}$ or $\mathrm{Au}-\mathrm{Pd}$ capsules, together with 2-4 $\mathrm{wt} \% \mathrm{H} 2 \mathrm{O}-\mathrm{NaBr}$ solution containing different $\mathrm{Br}$ contents. The Br-doped glasses were finally synthesized at $1200-1250{ }^{\circ} \mathrm{C}$ and 300-400 MPa in an internally heated pressure vessel (IHPV) at the Institut des Sciences de la Terre d'Orléans (ISTO, France).

These glasses were later characterized by electron microprobe (EMP, major elements), and $\mathrm{Br}$ contents determined by Instrumental Neutron Activation Analysis (INAA), Rutherford Backscattering Spectroscopy (RBS), X-Ray Fluorescence spectroscopy (SR-XRF), SIMS and/or LA-ICPMS. The different techniques enable Br quantitative analysis down to $\sim 1-10$ ppm with an accuracy from $<10$ to $\sim 20 \%$ depending on the method and $\mathrm{Br}$ concentrations (e.g., $<10 \%$ for $\mathrm{Br} \geq 10 \mathrm{ppm}$ and $>25 \%$ for $\mathrm{Br} \leq 5 \mathrm{ppm}$ for SR-XRF; $\leq \mathbf{2 0} \%$ for $\mathrm{Br}>\mathbf{1 0 0 p p m}$ by LA-ICPMS; $<\mathbf{2 0 \%}$ for $\mathrm{Br} \leq \mathbf{1 . 2} \mathrm{ppm}$ with SIMS) The details of glass synthesis and $\mathrm{Br}$ quantitative analyses can be found in Louvel (2011) and Cadoux et 


\section{High-Energy Resolution Fluorescence Detected X-ray Absorption Spectroscopy}

\section{(HERFD-XAS)}

X-ray absorption is a powerful technique to obtain information about the local

K-edge $=13474 \mathrm{eV})$ and the extended X-ray absorption fine structure (EXAFS). Both parts carry information about the local structure of the absorbing atom, including oxidation state, nature and number of nearest neighbours (oxygen, ligands, metals, etc...), bond length and symmetry. Additionally, pre-edge features located 50 to $30 \mathrm{eV}$ before the absorption edge provide complementary information about site geometry and electronic structure of the absorbing atom (e.g., $1 \mathrm{~s}=>4 \mathrm{p}$ transition). Their position and intensities can also be related to different oxidation states of the excited element (e.g., $\mathrm{Ti}^{4+/ 5+} ; \mathrm{Fe}^{2+/ 3+}-$ Farges et al.,1996; Wilke et al., 2004) or bond distance to the nearest neighbour (i.e, the shorter the bond length, the higher the pre-edge peak). In conventional XAS, total fluorescence yield is acquired with solid-state detectors (SSD or SDD). The energy bandwidth $\Delta \mathrm{E}$ of such detectors classically ranges between 120 and $300 \mathrm{eV}$, depending on the detector quality and shaping time, enabling detection limits in the order of $50 \mathrm{ppm}$. In comparison, a crystal analyser system (CAS) equipped with spherically bent crystal analysers with a radius of curvature in the $1 \mathrm{~m}$ range (Fig. 1A) decreases the energy bandwidth to $0.2-2 \mathrm{eV}$. This value

177 being smaller than the core-hole lifetime of the fluorescence line results in improved spectral 178 features (Fig. 1B). 
The beamline optics were tuned to Br K-edge energy $(13474 \mathrm{eV})$ using a double-crystal $\mathrm{Si}(220)$ monochromator and Rh-coated mirrors to focus the X-ray beam down to $100 \times 300$ $\mu \mathrm{m}(\mathrm{HxV}$ at FWHM). Then, energy selection of the emitted photo-electrons was accomplished using a CAS involving five spherically bent $\mathrm{Si}(880)$ crystal analysers aligned with the sample and a Vortex silicon drift detector (SDD2) on intersecting Rowland circles (Fig. 1A and C). These crystals can be considered as secondary monochromators that re-focus the diffracted beams on the fluorescence detector. Note that the current BM16 set-up now includes up to14 crystals ( $\mathrm{Si}$ or $\mathrm{Ge}$ ). The experimental set-up also includes another SDD for total fluorescence yield (SDD 1 on Fig. 1A). The incident energy and beamline optics were calibrated to a $\mathrm{Pb}$ foil reference (13035 eV - L3 edge). For the measurements, pristine glass pieces were placed between kapton foils on a motorized sample holder. A helium-filled bag was placed between the sample, the crystal analyser spectrometers (CAS), and the detector (SDD 2) in order to reduce attenuation of the fluorescence signal by air (Fig. 1C). Overall, this set-up enables an energy resolution of $\sim 1 \mathrm{eV}$, smaller than the core-hole lifetime of the fluorescence line (Hamalaien et al., 1991). XAS spectra were collected from 13390 to 13930 $\mathrm{eV}$ with $0.2 \mathrm{eV}$ steps in the pre-edge/white line region and $2.5 \mathrm{eV}$ steps in the EXAFS region (counting time 10s). When necessary, the incident beam was attenuated by the placement of aluminium foils within the beam path. An average of 10 spectra was collected on each sample.

EXAFS analysis was conducted using the Athena and Artemis packages (Ravel and Newville, 2005). The XAS spectra were averaged, normalized to the absorption edge step and background was removed using the automatic background subtraction routine AUTOBK included in Athena (Newville, 2001). The absorption edge E0 was set at the maxima of the absorption edge first derivative $(13474 \mathrm{eV})$. The $\mathbf{R}_{\mathbf{b k g}}$ parameter, which is a background 
The $\chi(\mathrm{k})$ EXAFS function were Fourier filtered over the $2.5-7 \AA^{-1}$ range. To take into account the chemical complexity of natural glasses and all the different atomic species that could bond to bromine in the glasses, different correlation models involving 2 to 3 neighbours $(\mathrm{O}, \mathrm{Na}, \mathrm{K}$ or $\mathrm{Ca}$ ) were tried during the fitting of EXAFS oscillations. For all samples, modelling of the EXAFS oscillations was performed using 4 variables: average coordination number $(\mathrm{N})$, distance to nearest neighbour (R), Debye-Waller factor $\sigma^{2}$ (accounts for structural disorder), and the energy shift $\Delta \mathrm{E}$. The amplitude factor $\mathrm{S}_{0}^{2}$ was fixed to 1 as previously used for similar studies on $\mathrm{Br}$ in high pressure, high temperature fluids and melts (Ferlat et al., 2002; Da Silvacorrelations between $\mathrm{N}$ and $\sigma^{2}$, and $\mathrm{R}$ and $\Delta \mathrm{E}$ (Pokrovski et al., 2009a,b).

\section{RESULTS AND DISCUSSION}

\section{Pre-edge and XANES features}

Figure 2 shows Br K-edge XANES spectra for four glasses: B3000, A100, RD500 and concentrations, the spectra for A10 and RD10 are too noisy to be analysed and will not be further discussed. All glasses display a sharp white line that peaks at around $13477 \mathrm{eV}$, characteristic of $\mathrm{Br}^{-}$. The effect of the crystal analyser spectrometer further reveals the presence of pre-edge features that had not been recorded with conventional XAS and result in an overall higher amplitude of both the white line and the first post-edge oscillations. 
Less polymerized basaltic and andesitic glasses share very similar XAS features (both XANES and EXAFS - Fig. 2 and 3), with the first oscillation after the white line peaking around $13494 \mathrm{eV}$. Slight differences may be recorded in the normalized amplitude of the white line, which is slightly more intense for basaltic composition (both 600 and $3000 \mathrm{ppm}$ ). Also, a latent pre-edge shoulder may be seen in the andesitic glass (Fig. 2). Pre-edge features are increasingly defined in the rhyodacite and haplogranite samples. In the rhyodacite, it consists of a large shoulder at $13471\left(-3 \mathrm{eV}\right.$ to $\left.\mathrm{E}_{0}\right)$, preceded by a smaller feature at $13.467(-7$ $\mathrm{eV}$ to $\left.\mathrm{E}_{0}\right)$. In the haplogranite, only one well-defined feature is located at $13468 \mathrm{eV}(-6 \mathrm{eV}$ to $\left.\mathrm{E}_{0}\right)$. Pre-edge features at the $\mathrm{Br}$ K-edge are attributed to the transition from the $1 \mathrm{~s}$ core level to an unfilled $p$ state and have previously been reported for compounds were $\mathrm{Br}$ is covalently bonded to itself $\left(\mathrm{Br}_{2}\right)$, hydrogen $(\mathrm{HBr})$, oxygen or carbon atoms (Burattini et al., 1991; D'Angelo et al., 1993; Evans et al., 2007). Alternatively, the development of such features could also probe different atom-atom interferences (i.e., effect of different network-modifiers) or changes in the symmetry of the local structure, as previously evidenced for Mn-, Fe- or Ti-bearing glasses (Chalmin et al., 2009; Romano et al., 2000). Further modelling of the effect of specific structural variations on the XANES spectra of Br-bearing glasses (for instance using the FDMNES code; Joly, 2001) is unfortunately impossible as molecular dynamic (MD) simulations for $\mathrm{Br}$ are lacking.

There is also a significant change in the post-edge oscillations: in the rhyodacite, similar shape as in basaltic and andesitic glasses are reported, only shifted to lower energy by $2 \mathrm{eV}$; the shape is completely different for the haplogranite glass, with a sharper first oscillation located at $13490 \mathrm{eV}$. Altogether, changes in the pre- and post-edge features of the spectra evidence both a gradual structural change from basaltic to rhyodacite composition, probably induced by increasing polymerization of the glass, and marked differences in the local environment of the haplogranite. The main difference between haplogranite and the other composition lies in the absence of divalent cations $\left(\mathrm{Ca}^{2+}, \mathrm{Mg}^{2+}, \mathrm{Fe}^{2+}\right)$ in the former, and it is 
thus likely that differences between basalt/andesite/rhyodacite and haplogranite arise from the formation of $\mathrm{Br}-\left(\mathrm{Ca}^{2+} / \mathrm{Mg}^{2+} / \mathrm{Fe}^{2+}\right)$ bonds in the natural volcanic compositions.

\section{EXAFS}

Despite the recourse to HERFD-XAS, EXAFS oscillations remain relatively weak and

noisy and do not extend over a much larger k-space range $\left(<8 \AA^{-1}-\right.$ Fig. $\left.3 \mathrm{~A}\right)$ than previously reported in Cochain et al. (2015) and Louvel (2011). However, EXAFS analysis is possible for all glasses with $\mathrm{Br}$ concentrations down to $100 \mathrm{ppm}$, significantly smaller than in previous studies. The small amplitude of the EXAFS oscillations results both from the long Br-

nearest neighbour distances and the different contribution of several pair correlations $(\mathrm{Br}-$ cation and $\mathrm{Br}-\mathrm{O}$ ), a fact that was also highlighted for $\mathrm{Cl} \mathrm{K}$-edge EXAFS in borosilicate glasses (McKeown et al., 2011). The Fourier transforms for basalt, andesite and rhyodacite glasses are characterized by a main contribution at $2.57 \AA$ and a small shoulder at $1.73 \AA$ (Fig. $3 \mathrm{C}$ - uncorrected positions shifted to about $-0.5 \AA$ with respect to the real average bond distance). There are no obvious contribution from second-shell neighbors above $3.5-4 \AA$. In comparison, the haplogranite glass only display one broad contribution at $2.28 \AA$. This contribution is similar to that in crystalline $\mathrm{NaBr}$ (Fig. 3C), suggesting that $\mathrm{Br}$ may be found in haplogranite in a 'salt-like' structure surrounded by $\mathrm{Na}$ atoms.

A simple approach to derive structural parameters for poorly structured glasses or solutions consist in using a crystalline standard as a structural fingerprint of bond length. For $\mathrm{Br}$, available structural data and XAS spectra are mostly limited to alkali and alkaline earth halides (NaBr, $\left.\mathrm{KBr}, \mathrm{CaBr} 2, \mathrm{FeBr}_{2}\right)$ (Cochain et al., 2015). For these compounds, $\mathrm{Br}-\mathrm{X}$ bond lengths increase in the following order: $\mathrm{Fe}-2.63<\mathrm{Mg}-2.70<\mathrm{Ca}-2.89<\mathrm{Na}-2.98<\mathrm{K}-$ oscillations and FT (Fig.3 ). 
To ensure a valid description of the Br surroundings in the different glasses, EXAFS fits were first performed for crystalline $\mathrm{NaBr}$ and the haplogranite glass, which have the simplest structures, only involving $\mathrm{Na}, \mathrm{O}, \mathrm{Si}$ and $\mathrm{K} . \Delta \mathrm{E}_{0}$ (energy misfit) derived for crystalline $\mathrm{NaBr}$ was fixed to fit the haplogranite glass. Consequently, the best fit for the haplogranite glass is obtained considering a 'salt-like structure' composed of $\sim 6 \mathrm{Na}$ atoms located at $2.87 \pm 0.01 \AA$ from the $\mathrm{Br}$ atom and $\sim 4$ oxygen nearest-neighbours at $\sim 3.40 \AA$. The Debye-Waller $\sigma^{2}$ for $\mathrm{Br}-\mathrm{Na}$ is fitted as 0.038 , a similar value to that obtained for crystalline $\mathrm{NaBr}$ (Table 2). These structural parameters closely match those from previous measurements conducted on the Haplo_1wt $\%$ glass in a hydrothermal diamond anvil cell at the X05-LA beamline at the Swiss Light Source (Louvel, 2011). The slight differences in the two datasets (e.g., $5.8 \pm 0.7$ versus $5.9 \pm 1.8 \mathrm{Na}$ atoms, located at a distance of $2.87 \pm 0.01$ versus $2.94 \pm 0.03 \AA$ ) likely arise from the different experimental geometry and the different k-range used in the present study (2.5-7 $\AA^{-1}$ in comparison to $\left.1.5-6 \AA^{-1}\right)$. These differences remain within error, with $\mathrm{Br}$ surrounded by $\sim 6 \mathrm{Na}$ atoms and oxygens next-nearest neighbours from the tetrahedral network.

The same approach was then used for the $\mathrm{B} 3000$ basaltic glass, fixing both $\Delta \mathrm{E}_{0}$ and DebyeWaller $\sigma^{2}$ from Br-Na before fitting. The best fit for this composition consequently involves $2.2 \pm 0.3 \mathrm{Na}$ at an average distance of $2.97 \pm 0.02 \AA$ and two other contributions located at 3.31 $\left(\mathrm{X}_{1}\right)$ and $3.59\left(\mathrm{X}_{2}\right) \AA$. Based on known crystalline bond distances, the first unknown contribution $\mathrm{X}_{1}$ may correspond to Br-K bonds (Wyckoff, 1963). The later one does not match any previously reported contributions and could potentially arise from $\mathrm{Si}$ or $\mathrm{Al}$ from the network, divalent cations in network-modifying positions $\left(\mathrm{Ca}^{2+}, \mathrm{Mg}^{2+}\right.$ or $\left.\mathrm{Fe}^{2+}\right)$ or $\mathrm{Br}-\mathrm{Br}$ bonding. Halogens-Si and -Al bonding, involving $\mathrm{Br}$ or $\mathrm{Cl}$ have previously been discarded based on similarities between Al-free and Al-rich glasses (Sandland et al., 2004). Br-Br bonds of 2.5-2.6 $\AA$ have been reported for polybromides (Pichierri, 2011). However, the haplogranite glass, which has the highest $\mathrm{Br}$ concentration, does not show the $\mathrm{X}_{2}$ contribution, 
and it hence seems unlikely that other glasses containing significantly smaller fraction of $\mathrm{Br}$ should involve $\mathrm{Br}-\mathrm{Br}$ bonds. Furthermore, $\mathrm{Br}-\mathrm{Br}$ gives rise to a pre-edge contribution, which is not present in those glasses (except RD500). On the contrary, $\mathrm{Cl}$ has been reported to bond to divalent $\mathrm{Ca}^{2+}$ in borosilicate and (an)hydrous aluminosilicate glasses (Baasner et al., 2014a; Evans et al., 2008; Sandland et al., 2004; McKeown et al., 2011). Therefore, we suggest this third-nearest neighbour to be $\mathrm{Ca}^{2+}$. The higher concentrations of $\mathrm{Ca}^{2+}$ compared to $\mathrm{Mg}^{2+}$ and $\mathrm{Fe}^{2+}$ in our glass compositions further support this hypothesis.

Similarly to the B3000 glass, adding up to 3 different contributions (Br-Na, $\mathrm{Br}-\mathrm{K}$ and $\mathrm{Br}-\mathrm{Ca}$ ) improved the quality of fits for B600, A100 and RD500 glasses (Table 2). For all natural glasses, fits involving a single scattering path (ie., $\mathrm{Br}-\mathrm{Na}, \mathrm{Br}-\mathrm{K}$ or $\mathrm{Br}-\mathrm{Ca}$ ) or a simple combination of $\mathrm{Br}-\mathrm{O}$ and $\mathrm{Br}-\mathrm{Na} / \mathrm{Ca} / \mathrm{K}$ as in the haplogranite systematically resulted in physically unrealistic parameter values (i.e., extremely large coordination numbers or negative Debye-Waller factors). The B600 best fit mostly mimics that of B3000 glass with an average of $2.5 \pm 0.2 \mathrm{Na}, 4.7 \pm 0.4 \mathrm{X}_{1} / \mathrm{K}$ and $3.7 \pm 0.4 \mathrm{X}_{2} / \mathrm{Ca}$ atoms surrounding $\mathrm{Br}$. Fitted $\mathrm{Br}$ $\mathrm{Na}, \mathrm{Br}-\mathrm{K}$ and $\mathrm{Br}-\mathrm{Ca}$ coordination numbers all increase for the andesite $\mathrm{A} 100$ and rhyodacite RD500 glasses. While it is likely that increasing fraction of $\mathrm{Na}$ in andesitic and especially rhyodacitic compositions will favour the development of 'salt-like' structure similar to that observed in Haplo_1wt\%, the increasing number of $\mathrm{Br}-\mathrm{K}$ and especially $\mathrm{Br}-\mathrm{Ca}$ seem more unlikely and may underline limitations in our fitting procedure. Yet, the similar EXAFS shape for all natural glasses supports that a local environment involving three different cations as derived for basalt $\mathrm{B} 3000$ and $\mathrm{B} 600$ should pertain with increasing $\mathrm{SiO}_{2}$ and decreasing $\mathrm{CaO}$ in the glasses. In the future, more detailed characterization of $\mathrm{Br}$ speciation in natural glasses may require using ${ }^{81} \mathrm{Br}$ Magic Angle Spinning Nuclear Magnetic Resonance (MAS NMR) (Trill et al., 2002).

\section{IMPLICATIONS}




\section{Halogens incorporation in silicate melts}

Our XAS analyses for natural basalt, andesite and rhyodacite suggest that $\mathrm{Br}$ may be surrounded by three different neighbours in these glasses: the first one is $\mathrm{Na}^{+}$in a salt-like structure and is probably more common in alkali-rich silicic compositions; the two others may be $\mathrm{K}^{+}$and $\mathrm{Ca}^{2+}$. Whether these different bonds occur on a localized domain where network modifiers are mixed together or in distinct clusters containing only $\mathrm{Na}^{+}, \mathrm{K}^{+}$or $\mathrm{Ca}^{2+}$ is difficult to assess as our XAS spectra average the structural information over the excited surface (100x300 $\mu \mathrm{m} \mathrm{HxV} \mathrm{FWHM).} \mathrm{However,} \mathrm{current} \mathrm{knowledge} \mathrm{of} \mathrm{aluminosilicate} \mathrm{glass} \mathrm{structure}$ supports that aluminosilicate melts do not show a random organization where the so-called network-modifiers $(\mathrm{Na}, \mathrm{K}, \mathrm{Ca}, \mathrm{Mg}, \mathrm{Fe})$ are dispersed within the tetrahedral network, but that network-modifiers segregate into distinct clusters or percolation channels in a depolymerized silicate tetrahedral network (Kargl and Meyer, 2008; Lee and Stebbins, 2003; LeLosq et al., 2017).

We believe the proposed structure involving three distinct neighbours (Fig. 4) should pertain in high-temperature volcanic/magmatic melts. Whether measurements on quenched glasses probe a more ordered speciation than that of their high P-T liquid counterparts has been a matter of debate for years. However, an increasing number of in-situ high-temperature spectroscopic analyses supports that structural changes associated to fast quench below the glass transition remain relatively small when dealing with 'low' pressure conditions $(<2-3$

GPa) (Drewitt et al., 2013; Le Losq et al., 2017; Malfait et al., 2018). For instance, in-situ Xray scattering analyses of Fe local environment by Drewitt et al. (2013) mostly report a small shortening of bond distances from liquid to glassy basalts at ambient pressure $( \pm 0.05 \AA)$. For Br, previous in-situ XAS by Cochain et al. (2015) suggested significant re-ordering associated with melting, resulting in an increase of $\mathrm{Br}-\mathrm{Na}$ bond length from 2.98 (as in $\mathrm{NaBr}$ ) to 3.55$3.75 \AA$ at pressure above $2 \mathrm{GPa}$. We however note that the Br K-edge EXAFS reported by Cochain et al. (2015) for granitic glass $(2.3 \mathrm{wt} \% \mathrm{Ca})$ share more similarity with our basaltic, 
andesitic and rhyodacitic glasses than with $\mathrm{Ca}$-free haplogranite, with the fitted $\mathrm{Br}-\mathrm{X}$ bond length of 3.55-3.75 $\AA$ similar to the one we here attribute to Br-Ca. Thus, the importance of multi-site incorporation and potential Ca-complexation may have been underestimated in this study.

Overall, we argue $\mathrm{Br}$ shows no particular affinity for $\mathrm{Na}$ over other network-modifier cations and may actually occur in three different sites, involving either $\mathrm{Na}^{+}, \mathrm{K}^{+}$or $\mathrm{Ca}^{2+}$ (Fig. 4). Similar environment was previously suggested for $\mathrm{Cl}$ in boro- and aluminosilicate glasses (Baasner et al., 2014a; McKeown et al., 2011). More surprisingly, F-Ca sites have also been found to be dominant in peralkaline aluminosilicate glasses, even with $\mathrm{Ca}$ being the least common cation (Baasner et al., 2014b). However, Iodine appears to favour a site-selective configuration, bonding to $\mathrm{Na}^{+}$even in the presence of large $\mathrm{Ca}$ amounts (up to $12 \mathrm{~mol} \%$ ) (Cicconi et al., 2019; McKeown et al., 2015). McKeown et al. (2011, 2015) attributed Cl and I different local environments to their different ionic radius $(1.81 \AA$ for $\mathrm{Cl}$ in comparison to 2.2 $\AA$ for I), which results in $\mathrm{Cl}$ having a larger charge density and hence greater affinity for higher charged cations. Br's ionic radius $(1.96 \AA)$ is closer to that of $\mathrm{Cl}$, which could support its complexation with divalent $\mathrm{Ca}^{2+}$.

\section{Potential influence on halogens degassing}

The efficiency of halogens degassing, and their potential fractionation from one another, depends on a complex interplay between P-T conditions, magma composition and eruption dynamics and kinetics (i.e., do halogens actually have time to diffuse and degas upon magma ascension?) (Balcone-Boissard et al., 2009). If occurring under equilibrium conditions, the efficiency of halogens degassing will solely depend on their fluid-melt partitioning; however, degassing may also occur out of equilibrium, and the final composition of the volcanic gas may then depend on diffusion rates rather than partition coefficients. 
Experimental fluid-melt partition coefficients underline the preferential partitioning of $\mathrm{Cl}, \mathrm{Br}$ and $\mathrm{I}$ in aqueous fluids or gas (Bureau et al., 2000, 2016; Cadoux et al., 2018; Webster et al., 2018 and references therein). Nevertheless, comparison between melt inclusions and residual volcanic glasses suggest that at least a tenth of the pre-eruptive $\mathrm{Cl}$ and $\mathrm{Br}$ contents may be retained in the erupted lava (Dolejs and Zajacz, 2018 and references therein). In natural systems, chemical controls on halogen degassing may especially be difficult to distinguish from the effects of eruption dynamics. Indeed, while fluid-melt partition coefficients increase slightly with $\mathrm{SiO}_{2}$ contents under typical volcanic conditions (900-1100 C and 100-200 MPa)(Cadoux et al., 2018; Dolejs and Zajacz, 2018; Webster et al., 2018 and references therein), comparison between the residual halogen contents from plinian clasts and lava domes suggest that fast decompression during explosive eruptions prevents equilibrium between the different volatiles species and consequently precludes degassing of halogens with $\mathrm{H}_{2} \mathrm{O}$ (Balcone-Boissard et al., 2010). The similarities we report in the incorporation mechanisms of $\mathrm{Br}$ (and $\mathrm{Cl}$ ) in basaltic, andesitic, and to a lesser extent, rhyodacitic melts suggest that the effect of melt composition and structure on $\mathrm{Cl}$ and $\mathrm{Br}$ initial solubility and degassing from hydrous calc-alkaline melts may be relatively small and mostly linked to the larger availability of interstitial alkali and alkaline-earth rich domains in less polymerized basaltic and andesitic compositions. In the case of fast explosive degassing, large amount of $\mathrm{Cl}$ and $\mathrm{Br}$ may also be retained in alkali and alkaline earth-rich domains depleted in water, as suggested by the similar speciation reported in anhydrous versus hydrous sodium disilicate and haplogranite glasses (Louvel, 2011).

Similarities in the local environment of $\mathrm{Br}$ in basaltic to rhyodacite compositions also point to $\mathrm{Br}$ (and by extension $\mathrm{Cl}$ ) having comparable diffusion rates in hydrated and $(\mathrm{Na}, \mathrm{K}, \mathrm{Ca})$ bearing melts. Balcone-Boissard et al. (2009) reported that alkali content affects $\mathrm{Cl}$ diffusivity so that $\mathrm{Cl}$ diffuse faster in $\mathrm{K}$-bearing phonolitic melts. They attributed this different behaviour to stronger $\mathrm{Cl}-\mathrm{Na}$ interactions that would slow down $\mathrm{Cl}$ diffusion and potentially prevent $\mathrm{Cl}$ 
degassing upon fast eruption. However their experiments did not consider the effect of $\mathrm{Ca}$ (Ca-free glass) and the reported differences may not hold to natural composition including several wt $\% \mathrm{CaO}$. Experiments on Ca-rich basaltic compositions by Alletti et al. (2009) show no significant differences in the diffusivity of $\mathrm{F}, \mathrm{Cl}$ and $\mathrm{Br}$ under anhydrous and hydrous conditions $\left(\mathrm{D}=3-410^{11} \mathrm{~m}^{2} \mathrm{~s}^{-1}\right.$ at $1250{ }^{\circ} \mathrm{C}$ and $\left.1 \mathrm{GPa}\right)$, suggesting limited effect of ionic radius and preferential complexation on halogen diffusion for this composition. Coupled degassing of $\mathrm{Cl}$ and $\mathrm{Br}$ should also be expected, regardless of their initial contents in the melt. This is further supported by the relatively constant $\mathrm{Cl} / \mathrm{Br}$ reported in both volcanic gas and residual volcanic glasses from various tectonic settings (e.g., Hawaii, Nyiragongo, Etna, Stromboli, Reunion, Masaya or Montserrat; Balcone-Boissard et al., 2010; Cadoux et al., 2018; Villemant et al., 2008).

Larger controls on $\mathrm{F}, \mathrm{Cl}, \mathrm{Br}$ and I degassing efficiency may arise from the crystallization of phases such as apatite, hauyne or nosean, which act as sinks for the halogens and retain them in the magma. McKeown et al. (2015) demonstrated that I-Na environment in borosilicate glasses mimics that of NaI-sodalite. Such an environment could act as precursor to the crystallization of halogens-rich minerals and significantly hinder I degassing. While hauyne, nosean and apatite have all been suggested to crystallize in phonolite at $\mathrm{Cl}$ concentrations close to or below melt saturation (Baudoin and Parat, 2015) and are common late-stage phases of volcanic activity that crystallize below $1000{ }^{\circ} \mathrm{C}$ and $300 \mathrm{MPa}$, the heterogeneous distribution of $\mathrm{Br}$ (and $\mathrm{Cl}$ ) within the melt structure could favour their transport in the ascending melts and ultimately lead to a more efficient degassing than for I.

\section{ACKNOWLEDGMENTS}

M. Louvel acknowledges funding by the Natural Environment Research (NERC) Council via grant NE/M000419/1 awarded to Michael J. Walter from the University of Bristol to support 

for handling of the manuscript.

\section{References}

Aiuppa, A., Baker, D. R., and Webster, J. D. (2009). Halogens in volcanic systems. Chemical Geology 263, 1-18. 467

Baasner, A., Hung, I., Kemp, T.F., Dupree, R., Schmidt, B.C., and Webb, S.L. (2014a). Constraints on the incorporation mechanism of chlorine in peralkaline and peraluminous $\mathrm{Na} 2 \mathrm{O}-\mathrm{CaO}-\mathrm{Al} 2 \mathrm{O} 3-$ $\mathrm{SiO} 2$ glasses. American Mineralogist 99, 1713-1723.

Baasner, A., Schmidt, B.C., Dupree, R., and Webb, S.L. (2014b). Fluorine speciation as a function of composition in peralkaline and peraluminous $\mathrm{Na} 2 \mathrm{O}-\mathrm{CaO}-\mathrm{A} 12 \mathrm{O} 3-\mathrm{SiO} 2$ glasses: A multinuclear NMR study. Geochimica et Cosmochimica Acta 132, 151-169.

Balcone-Boissard, H., Baker, D.R., Villemant, B., and Boudon, G. (2009). F and $\mathrm{Cl}$ diffusion in phonolitic melts: Influence of the $\mathrm{Na} / \mathrm{K}$ ratio. Chemical Geology 263, 89-98.

Balcone-Boissard, H., Villemant, B., and Boudon, G. (2010). Behavior of halogens during the degassing of felsic magmas. Geochemistry Geophysics Geosystems 11.

Bobrowski, N., Honninger, G., Galle, B., and Platt, U. (2003). Detection of bromine monoxide in a volcanic plume. Nature 423, 273-276.

Bordage, A., Papai, M., Sas. N.S., Szlachetko, J., Nachtegaal, M., and Vanko, G. (2013). On the sensitivity of hard X-ray spectroscopies to the chemical state of Br. Physical Chemistry, Chemical Physics, 15, 11088-1-11.

Brackett, E.B., Brackett, T.E., and Sass, R.L. (1963). The crystal structure of calcium bromide. Journal Inorganic Nuclear Chemistry 25, 1295-1296.

Bureau, H., and Métrich, N. (2003). An experimental study of bromine behaviour in water-saturated silicic melts. Geochimica et Cosmochimica Acta 67, 1689-1697. 
Bureau, H., Keppler, H., and Metrich, N. (2000). Volcanic degassing of bromine and iodine: experimental fluid/melt partitioning data and applications to stratospheric chemistry. Earth and Planetary Science Letters 183, 51-60.

Bureau, H., Auzende A-L., Marocchi, M., Raepsaet, C., Munsch, P., Testemale, D., Mezouar, M., Kubsky, S., Carriere, M., Ricolleau, A., and Fiquet, G. (2016). Modern and past volcanic degassing of iodine. Geochimica et Cosmochimica Acta 173, 114-125.

Burgisser, A., Alletti, M., and Scaillet, B. (2015). Simulating the behaviour of volatiles belonging to the C-O-H-S system in silicate melts under magmatic conditions with the software D-Compress. Computers and Geosciences 79, 1-14.

Cadoux, A., Scaillet, B., Bekki, S., Oppenheimer, C., and Druitt, T. H. (2015). Stratospheric ozone destruction by the Bronze-Age Minoan eruption (Santorini Volcano, Greece). Scientific Reports 5, 12243, doi:10.1038/srep12243.

Cadoux, A., Iacono-Marziano, G., Paonita, A., Deloule, E., Aiuppa, A., Nelson Eby, G., Costa, M., Brusca, L., Berlo, K., Geraki, K., Mather, T.A., Pyle, D.M., and Di Carlo, I. (2017). A new set of standards for in-situ measurements of bromine abundances in natural silicate glasses: Application to SR-XRF, LA-ICP-MS and SIMS techniques. Chemical Geology 452, 60-70.

Cadoux, A., Iacono-Marziano, G., Scaillet, B., Aiuppa, A., Mather, T.A., Pyle, D.M., Deloule, E., Gennaro, E., and Paonita, A. (2018). The role of melt composition on aqueous fluid vs. silicate melt partitioning of bromine in magmas. Earth and Planetary Science Letters 498, 450-463.

Calas, G., Brown Jr., G.E., Waychunas, G., and Petiau, J. (1987). X-ray absorption spectroscopic studies of silicate glasses and minerals. Physics and Chemistry of Minerals 15, 19-29.

Cicconi, M.R., Pili, E., Grousset, L., Florian, P., Bouillard, J.C., Vantelon, D., and Neuville D.R. (2019). Iodine solubility and speciation in glasses. Scientific Reports 9, 7758.

Chalmin, E., Farges, F., and Brown Jr., G.E. (2009). A pre-edge anlysis of Mn K-edge XANES spectra to help determine the speciation of manganese in minerals and glasses. Contribution to Mineralogy and Petrology 157, 111-126. 
Cochain, B., Sanloup, C., de Grouchy, C., Crepisson, C., Bureau, H., Leroy, C., Kantor, I., and Irifune, T. (2015). Bromine speciation in hydrous silicate melts at high pressure. Chemical Geology $404,18-26$.

D’angelo, P., Dicicco, A., Filipponi, A., and Pavel, N. V. (1993). Double-electron excitation channels at th $\mathrm{Br}$ K-edge of $\mathrm{HBr}$ and Br2. Physical Review A 47, 2055-2063.

Da Silva-Cadoux, C., Proux, O., Hazemann, J. L., James-Smith, J., Testemale, D., and Yamaguchi, T. (2009). X-ray absorption spectroscopy study of solvation and ion-pairing in aqueous gallium bromide solutions at supercritical conditions. Journal of Molecular Liquids 147, 83-95.

Deshpande, V. (1961). Thermal Expansion of Sodium Fluoride and Sodium Bromide. Acta Crystallographica 14, 794.

Dinger, F., Bobrowski, N., Warnach, S., Bredemeyer, S., Hidalgo, S., Arellano, S., Galle, B., Platt, U., and Wagner, T. (2018). Periodicity in the $\mathrm{BrO} / \mathrm{SO} 2$ molar ratios in the volcanic gas plume of Cotopaxi and ist correlation with the Earth tides during the eruption in 2015. Solid Earth 9, 247266.

Dolejs, D., and Zajacz, Z. (2018). Halogens in silicic magmas and their hydrothermal systems. In Harlov, D. and Aranovicj, L. (Eds) The role of halogens in Terrestrial and Extraterrestrial Geochemical Processes. Springer Geochemistry.

Drewitt, J.W.E., Sanloup, C., Bytchkov, A., Brassamin, S., and Hennet, L. (2013). Structure of (FexCa1-xO)y(SiO2)1-y liquids and glasses from high-energy x-ray diffraction: Implications for the structure of natural basaltic magmas. Physical Review B 87, 224201.

Evans, K. A., Mavrogenes, J., and Newville, M. (2007). The effect of $\mathrm{CO}_{2}$ on the speciation of bromine in low-temperature geological solutions: an XANES study. Journal of Synchrotron Radiation 14, 219-226.

Evans, K. A., Mavrogenes, J. A., O'Neill, H. S., Keller, N. S., and Jang, L. Y. (2008). A preliminary investigation of chlorine XANES in silicate glasses. Geochemistry Geophysics Geosystems 9.

Farges, F., Brown Jr., G.E., and Rehr, J.J. (1996). Coordination chemistry of Ti(IV) in silicate glasses and melts: I. XAFS study of titanium coordination in oxide model compounds. Geochimica et Cosmochimica Acta 60, 3023-3038. 
Farges, F., Linnen, R.L., and Brown Jr, G.E. (2006). Redox and speciation of tin in hydrous silicate glasses: A comparison with Nb, Ta, Mo and W. The Canadian Mineralogist 44, 795-810.

Haberecht, J., Borrmann, H., and Kniep, R. (2001). Refinement of the crystal structure of iron dibromide, $\mathrm{FeBr}_{2}$. Zeitschrift fur Kristallographie - New Crystal Structures 216, 510.

Hamalaien, K., Siddons, D.P., Hastings, J.B., and Berman, L.E. (1991). Elimination of the inner-shell lifetime broadening in X-ray absorption spectroscopy. Physical Review Letters 67, 2850-2853.

Joly, Y. (2001). X-ray absorption near edge structure calculations beyond the muffin-tin approximation. Physical Review B 63, 125120-125129.

Kargl, F., and Meyer, A. (2008). Na-relaxation and intermediate range structure in sodium-potassium silicate melts. Chemical Geology 256, 278-285.

Klobas, E.J., Wilmouth, D.M., Weisenstein, D.K., Anderson, J.G., and Salawitch, R.J. (2017). Ozone depletion following future volcanic eruptions. Geophysical Research Letters 44, 7490-7499.

Kutterolf, S., Hansteen, T. H., Appel, K., Freundt, A., Krüger, K., Pérez, W., and Wehrmann, H. (2013). Combined bromine and chlorine release from large explosive volcanic eruptions: A threat to stratospheric ozone? Geology, 41, 707-710, doi:10.1130/G34044.1.

Kutterolf, S., Hansteen, T. H., Freundt, A., Wehrmann, H., Appel, K., Krüger, K., and Perez, W. (2015). Bromine and chlorine emissions from Plinian eruptions along the Central American Volcanic Arc: From source to atmosphere. Earth and Planetary Science Letters, 429, 234-246.

Lee, S.K., and Stebbins, J.F. (2003). Nature o cation mixing and ordering in Na-Ca silicate glasses and melts. The Journal of Physical Chemistry B, 107, 3141-3148.

LeLosq, C., Neuville, D.R., Chen, W., Florian, P., Massiot, D., Zhou, Z., and Greaves, G.N. (2017). Percolation channels: a universal idea to describe the atomic structure and dynamics of glasses and melts. Scientific Reports 7, 16490.

Louvel, M. (2011). Trace elements in subduction zone fluids: Speciation, partitioning and the geochemical cycle of halogens and HFSE. PhD thesis, ETH Zurich.

Louvel, M., Sanchez-Valle, C., Malfait, W.J., Testemale, D., and Hazemann, J-L. (2013). Zr complexation in high pressure fluids and silicate melts and implications for the mobilization of HFSE in subduction zones. Geochimica et Cosmochimica Acta 104, 281-299. 
Lubcke, P., Bobrowski, N., Arellano, S., Galle, B., Garzon, G., Vogel, L., and Platt, U. (2014). $\mathrm{BrO} / \mathrm{SO}_{2}$ molar ratios from scanning DOAS measurements in the NOVAC network. Solid Earth $5,409-424$.

Malfait, W.J., 2018. Vibrational properties of glasses and melts. In Kono, Y. and Sanloup, C. (Eds) Magmas Under Pressure, Elsevier. Chapter 8, 211-236.

McKeown, D. A., Gan, H., Pegg, I. L., Stolte, W. C., and Demchenko, I. N. (2011). X-ray absorption studies of chlorine valence and local environments in borosilicate waste glasses. Journal of Nuclear Materials 408, 236-245.

McKeown, D.A., Muller, I.S., and Pegg, I.L. (2015). Iodine valence and local environments in borosilicate waste glasses using X-ray absorption spectroscopy. Journal of Nuclear Materials $456,182-191$.

Newville, M. (2001). EXAFS analysis using FEFF and FEFFIT. Journal of Synchrotron Radiation 8, 96-100. 581

Pichierri, F. (2011). Structure and bonding in polybromide anions $\mathrm{Br}-(\mathrm{Br} 2) \mathrm{n}(\mathrm{n}=1-6)$. Chemical Physics Letters 515, 116-121.

Proux, O., Lahera, E., Del Net, W., Kieffer, I., Rovezzi, M., Testemale, D., Irar M., Thomas, S., Aguilar-Tapia, A., Bazarkina, E., Prat, A., Tella, M., Auffan, M., Rose, J., and Hazemann, J-L. (2017). High-energy resolution fluorescence detected X-ray absorption spectroscopy: A new powerful structural tool in environemnetal biogeochemistry sciences. Journal of Environmental Quality 46, 1146-1157.

Ravel, B., and Newville, M. (2005). ATHENA, ARTEMIS, HEPHAESTUS: data analysis for X-ray absorption spectroscopy using IFEFFIT. Journal of Synchrotron Radiation 12, 537-541.

Roberts, T.J., Braban, C.F., Martin, R.S., Oppenheimer, C., Adams, J.W., Cox, R.A., Jones, R.L., and Griffiths, P.T. (2009). Modelling reactive halogen formation and ozone depletion in volcanic plumes. Chemical Geology 263, 151-163.

Roberts, T.J., Lurton, T., Giudice, G., Liuzzo, M., Aiuppa, A., Coltelli, M., Vignelles, D., Salerno, G., Coute, B., Chartier, M., Baron, R., Saffell, J.R., and Scaillet, B. (2017). Validation of a novel 

Multi-Gas sensor for volcanic $\mathrm{HCl}$ alongside $\mathrm{H} 2 \mathrm{~S}$ and $\mathrm{SO} 2$ at Mt. Etna. Bulletin of Volcanology 79: 36 .

Romano, C., Paris, E., Poe, B.T., Giuli, G., Dingwell, D.B. and Mottana, A., 2000. Effect of aluminium on Ti-coordination in silicate glasses: A XANES study. American Mineralogist 85, 108-117.

Sandland, T. O., Du, L. S., Stebbins, F., and Webster, J. D. (2004). Structure of Cl-containing silicate and aluminosilicate glasses: A 35Cl MAS-NMR study. Geochimica et Cosmochimica Acta 68, 5059-5069.

Seo, J.H., and Zajacz, Z. (2016). Fractionation of $\mathrm{Cl} / \mathrm{Br}$ during fluid phase separation in magmatichydrothermal fluids. Geochimica et Cosmochimica Acta 183, 125-137.

Seo, J.H., Guillong, M., Aerts, M., Zajacz, Z., and Heinrich, C.A., (2011). Microanalysis of S, Cl and $\mathrm{Br}$ in fluid inclusions by LA-ICP-MS. Chemical Geology 284, 35-44.

Signorelli, S., and Carroll, M. R. (2000). Solubility and fluid-melt partitioning of $\mathrm{Cl}$ in hydrous phonolitic melts. Geochimica et Cosmochimica Acta 64, 2851-2862.

Signorelli, S., and Carroll, M. R. (2002). Experimental study of Cl solubility in hydrous alkaline melts: constraints on the theoretical maximum amount of $\mathrm{Cl}$ in trachytic and phonolitic melts. Contributions to Mineralogy and Petrology 143, 209-218.

Stebbins, J. F., and Du, L. S. (2002). Chloride ion sites in silicate and aluminosilicate glasses: A preliminary study by Cl-35 solid-state NMR. American Mineralogist 87, 359-363.

Trill, H., Eckert, H., and Srdanov, V.I. (2002). Topotactic transformations of sodalite cages: Synthesis and NMR study of mixed salt-free and salt-bearing sodalites. Journal of the American Chemistry Society 124, 8361-8370.

Villemant, B., Mouatt, J., and Michel, A. (2008). Andesitic magma degassing investigated through $\mathrm{H}_{2} \mathrm{O}$ vapour-melt partitioning of halogens at Soufriere Hills Volcano, Montserrat (Lesser Antilles). Earth and Planetary Science Letters, 269, 212-229.

Vitova, T., Denecke, M.A., Gottlicher, J., Jorissen, K., Kas, J.J., Kvashina, K., Prussmann, T., Rehr, J.J., and Rothe, J. (2013). Actinide and lanthanide speciation with high-energy resolution X-ray techniques. Journal of Physics: Conference Series 430, 012117. 
Von Glasow, R., Bobrovski, N., and Kern, C. (2009). The effects of volcanic eruptions on atmospheric chemistry. Chemical Geology 263, 131-142.

Webster, J. D., Baker, D.R., and Aiuppa, A. (2018). Halogens in mafic and intermediate silica content magmas. In Harlov, D. and Aranovicj, L. (Eds) The role of halogens in Terrestrial and Extraterrestrial Geochemical Processes. Springer Geochemistry. Under Presssure, Elsevier. Chapter 6, pp 155-178. state in basaltic glasses using XANES at the K-edge. Chemical Geology 213, 71-87.

Wyckoff, R.W.G. (1963). Crystal Structures, Second Edition. Interscience Publishers. melts: Constraints from $\mathrm{H}-1$ and Si-29 NMR spectroscopy and ab initio calculations. Geochimica Et Cosmochimica Acta 68, 5027-5057. 
Fig. 2. Normalized XANES spectra for basaltic (B3000), andesitic (A100), rhyodacitic (RD500) and haplogranitic (Haplo_1wt\%) glasses. HERFD-XAS spectra from $\mathrm{NaBr}$ and

\section{LIST OF TABLE AND FIGURES}

Table 1. Composition of Br-bearing glasses.

*H2O (wt\%) measured by SIMS; **H2O nominal; ***Br contents measured by Instrumental Neutron Activation Analysis INAA or Rutherford backscattering RBS (Haplo_1wt\%).

RD10_Dry represents the re-melted, i.e., water-free, RD10 standard glass from Cadoux et al. (2017).

Table 2. Structural parameters derived from the Br K-edge EXAFS analysis of the $\mathrm{NaBr}$ powder reference and the different silicate glasses.

$\mathrm{N}$ is the Br-X coordination number (where $X$ is the nearest to next-nearest atom, $\mathrm{O}, \mathrm{Na}, \mathrm{K}$ or $\mathrm{Ca}$ ); $\mathrm{R}$ is the average bond distance between $\mathrm{Br}$ and $\mathrm{X}$ in $A ; \sigma^{2}$ is the Debye-Waller factor (in $A^{2}$ ), which accounts for structural disorder around the excited atom. $\triangle E O$ is the energy misfit; R-factor and Xred are internal parameters describing the goodness of the fit that are used to select the optimal fit. All fits were conducted with a $\mathrm{SO}_{2}$ of 1 .

*parameters that were fixed during fitting procedure.

Fig. 1. (A) Schematic view of the experimental set-up for HERFD-XAS at the BM16 beamline of the ESRF (Grenoble, France). The emitted photons are first selected in energy with the crystal analyzers (CAS) and then collected by a standard SDD detector (SDD 2). (B) Comparison of XAS collected on the rhyodacite RD500 glass sample, using conventional XAS detection (SDD1 black line) and high-resolution energy (CAS+SDD2 - red line). (C) Photograph of the experimental set-up showing the glass samples, Helium bag and SDD2.

KBr crystalline powders, which are used as structural fingerprints, have been uploaded (https://www.sshade.eu)(10.26302/SSHADE/EXPERIMENT OP 20180115 002; 
Fig. 3. (A) $k^{2}$-weighted $\chi(k)$ EXAFS oscillations and (B) corresponding Fourier transforms

Fig. 4. Proposed schematic volcanic glass structure. $\mathrm{Br}$ is in $\mathrm{Na}, \mathrm{K}$ or Ca-rich domains within the partially depolymerized silicate tetrahedral network. Note that silicate tetrahedra may include 
Table 1.

\begin{tabular}{|l|l|l|l|l|l|l|l|}
\hline & B600 & B3000 & A10 & A100 & RD10_Dry & RD500 & $\begin{array}{l}\text { Haplo_1wt } \\
\%\end{array}$ \\
\hline $\mathrm{SiO}_{2}(\mathrm{wt} \%)$ & 46.49 & 47.01 & 56.70 & 55.58 & 70.10 & 67.14 & 75.0 \\
$\mathrm{TiO}_{2}$ & 1.65 & 1.64 & 1.06 & 1.14 & 0.44 & 0.39 & \\
$\mathrm{Al}_{2} \mathrm{O}_{3}$ & 15.42 & 15.66 & 15.3 & 15.26 & 14.63 & 13.82 & 9.4 \\
$\mathrm{FeO}_{\text {tot }}$ & 9.17 & 8.99 & 6.76 & 6.19 & 2.80 & 2.56 & \\
$\mathrm{MnO}$ & 0.17 & 0.18 & 0.22 & 0.24 & 0.08 & 0.13 & \\
$\mathrm{MgO}$ & 6.00 & 5.95 & 2.74 & 2.60 & 0.72 & 0.69 & \\
$\mathrm{CaO}$ & 9.84 & 9.90 & 6.18 & 6.08 & 2.30 & 2.28 & \\
$\mathrm{Na}_{2} \mathrm{O}$ & 3.03 & 3.22 & 4.01 & 4.33 & 4.17 & 4.56 & 7.4 \\
$\mathrm{~K}_{2} \mathrm{O}$ & 1.88 & 1.93 & 1.55 & 1.60 & 3.03 & 2.91 & 3.8 \\
$\mathrm{P}_{2} \mathrm{O}$ & 0.72 & 0.73 & 0.23 & 0.25 & 0.13 & 0.12 & \\
$\mathrm{H}_{2} \mathrm{O}$ & $2.0^{* *}$ & $2.07^{*}$ & $4.98^{*}$ & $4.90^{*}$ & $0.04^{*}$ & $4.75^{*}$ & $3.3^{* *}$ \\
$\mathrm{Br}(p p m)^{* * *}$ & 634 & 3240 & 9.9 & 90.3 & 10.0. & 496 & 9600 \\
\hline
\end{tabular}

685

686

687

688

689

690

691

692

693

694

695

696

697

698

699

700

701 
Table 2

\begin{tabular}{|c|c|c|c|c|c|c|c|}
\hline Glass & Shell & $\mathrm{N}$ & $\mathrm{R}(\AA)$ & $\sigma^{2}\left(\AA^{2}\right)$ & $\Delta \mathrm{E}_{0}(\mathrm{eV})$ & $R$-factor & Xred \\
\hline $\mathrm{NaBr}$ & $\mathrm{Na}$ & $5.83 \pm 0.35$ & $2.97 \pm 0.01$ & $0.038 \pm 0.002$ & $-2.7 \pm 0.3$ & 0.031 & \\
\hline \multirow[t]{3}{*}{ B 600} & $\mathrm{Na}$ & $2.53 \pm 0.25$ & $2.97 \pm 0.01$ & $0.038^{*}$ & \multirow[t]{3}{*}{$-2.7^{*}$} & \multirow[t]{3}{*}{0.014} & \multirow[t]{3}{*}{136} \\
\hline & $X_{l} / K$ & $4.67 \pm 0.37$ & $3.30 \pm 0.03$ & $0.011^{*}$ & & & \\
\hline & $\mathrm{X}_{2} / \mathrm{Ca}$ & $3.71 \pm 0.37$ & $3.57 \pm 0.01$ & $0.020^{*}$ & & & \\
\hline \multirow[t]{3}{*}{ B3000 } & $\mathrm{Na}$ & $2.22 \pm 0.34$ & $2.97 \pm 0.02$ & $0.038^{*}$ & \multirow[t]{3}{*}{$-2.7^{*}$} & \multirow[t]{3}{*}{0.013} & \multirow[t]{3}{*}{323} \\
\hline & $X_{1} / K$ & $4.46 \pm 0.27$ & $3.31 \pm 0.01$ & $0.011 \pm 0.002$ & & & \\
\hline & $\mathrm{X}_{2} / \mathrm{Ca}$ & $3.48 \pm 0.47$ & $3.59 \pm 0.02$ & $0.020 \pm 0.005$ & & & \\
\hline \multirow[t]{3}{*}{$\mathrm{A} 100$} & $\mathrm{Na}$ & $4.17 \pm 1.55$ & $3.03 \pm 0.07$ & $0.038^{*}$ & \multirow[t]{3}{*}{$-2.7^{*}$} & \multirow[t]{3}{*}{0.082} & \multirow[t]{3}{*}{242} \\
\hline & $X_{I} / K$ & $5.69 \pm 1.20$ & $3.31 \pm 0.05$ & $0.011^{*}$ & & & \\
\hline & $\mathrm{X}_{2} / \mathrm{Ca}$ & $6.09 \pm 1.80$ & $3.58 \pm 0.07$ & $0.020^{*}$ & & & \\
\hline \multirow[t]{3}{*}{ RD500 } & $\mathrm{Na}$ & $5.32 \pm 0.66$ & $2.96 \pm 0.03$ & $0.038^{*}$ & \multirow[t]{3}{*}{$-2.7^{*}$} & \multirow[t]{3}{*}{0.038} & \multirow[t]{3}{*}{204} \\
\hline & $X_{1} / K$ & $6.12 \pm 0.65$ & $3.28 \pm 0.03$ & $0.011^{*}$ & & & \\
\hline & $\mathrm{X}_{2} / \mathrm{Ca}$ & $6.84 \pm 0.77$ & $3.55 \pm 0.04$ & $0.020^{*}$ & & & \\
\hline \multirow[t]{2}{*}{ Haplo_1wt\% } & $\mathrm{Na}$ & $5.83 \pm 0.71$ & $2.87 \pm 0.01$ & $0.038 \pm 0.003$ & \multirow[t]{2}{*}{$-2.7^{*}$} & \multirow[t]{2}{*}{0.018} & \multirow[t]{2}{*}{85} \\
\hline & $\mathrm{O}$ & $3.44 \pm 0.96$ & $3.39 \pm 0.03$ & $0.020 \pm 0.010$ & & & \\
\hline
\end{tabular}

703

704 
A)

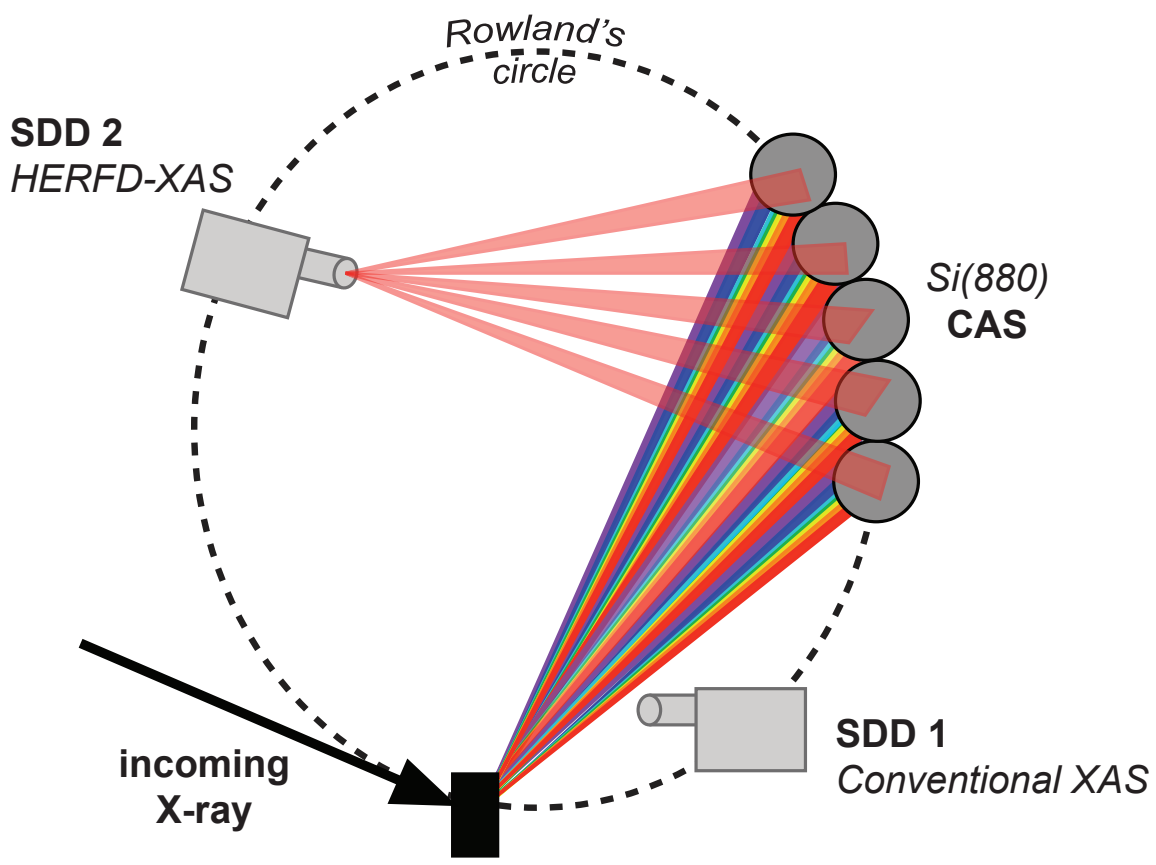

B)

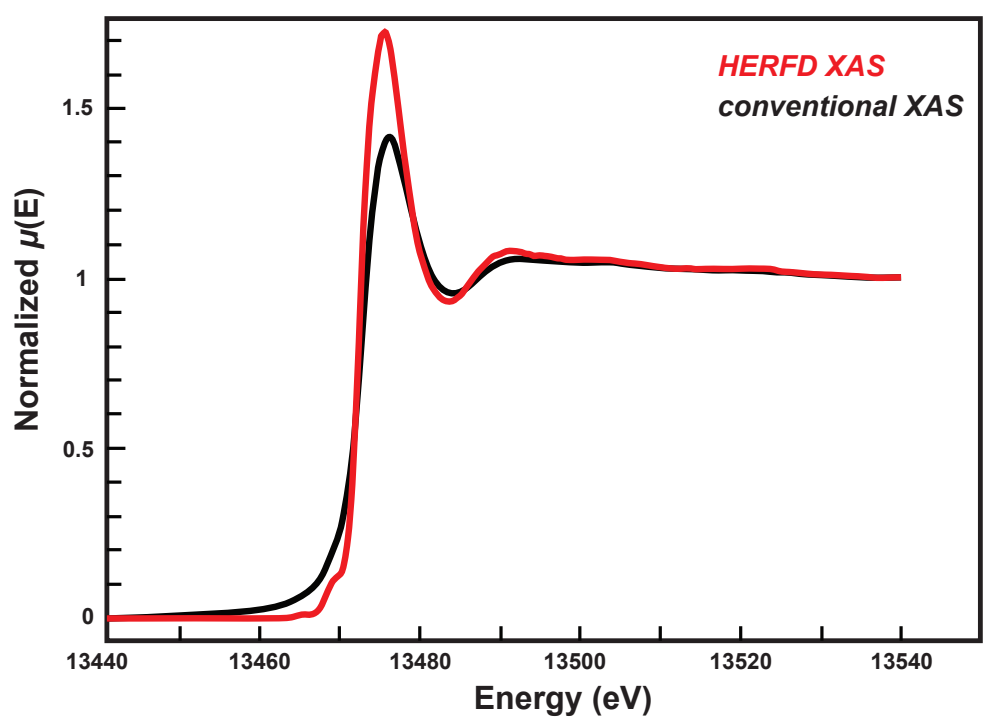

C)

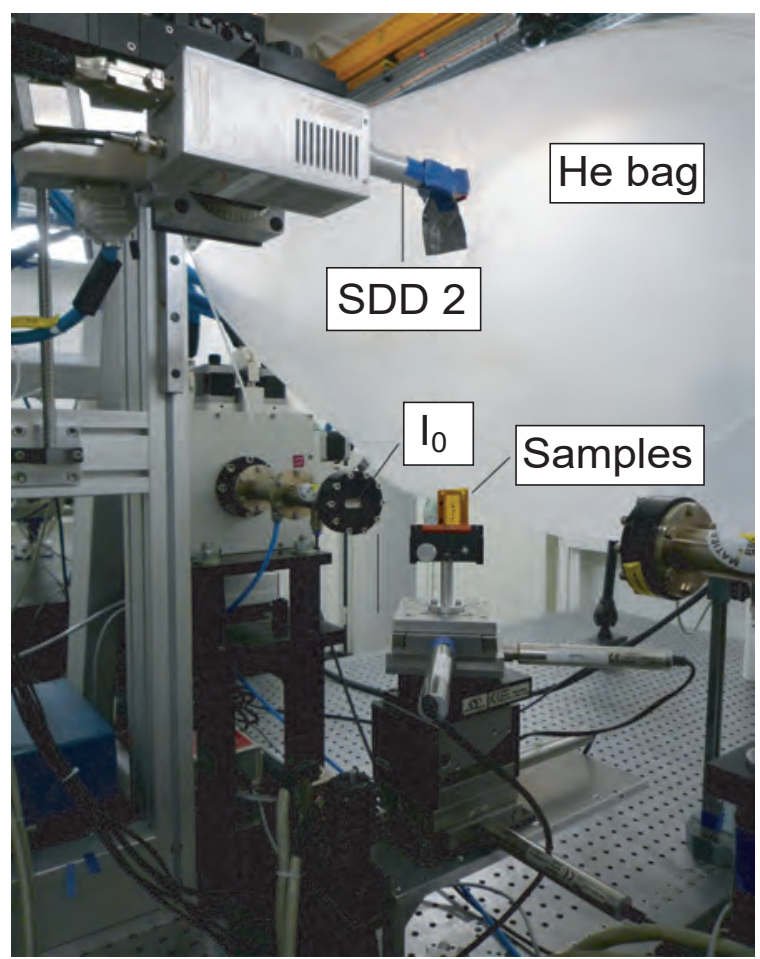



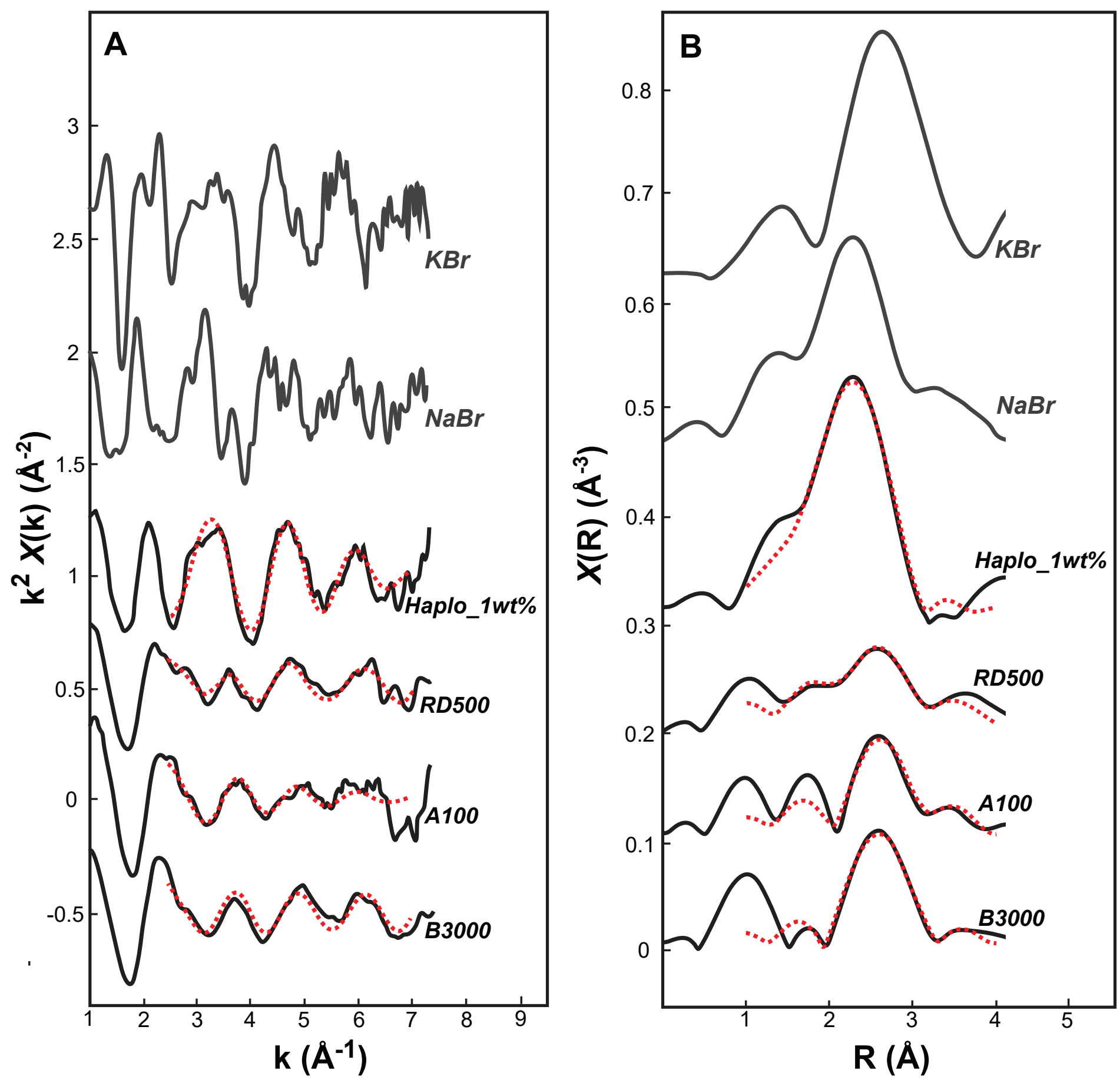

Figure 3 
Figure 4

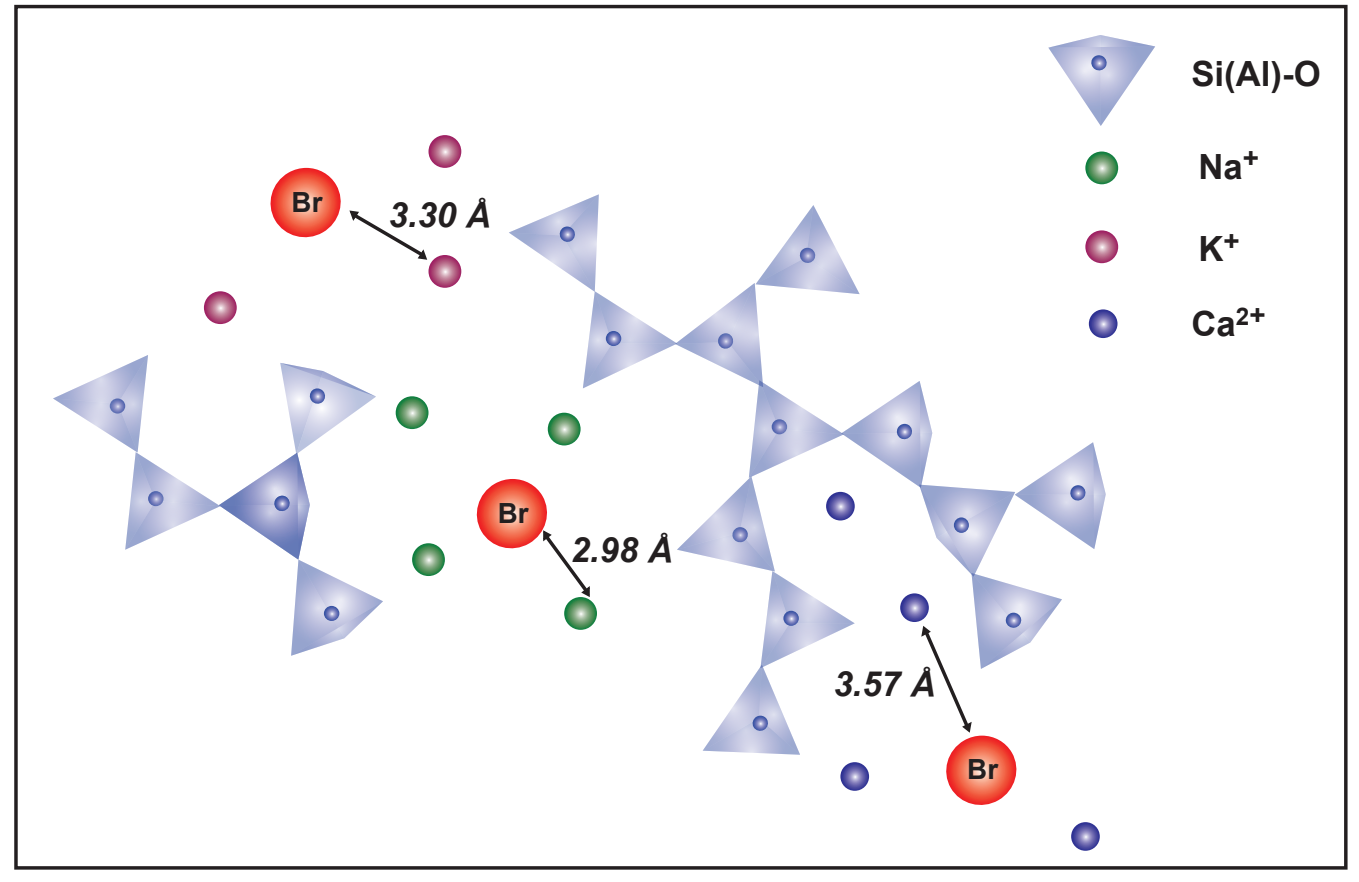


This is a preprint, the final version is subject to change, of the American Mineralogist (MSA) Cite as Authors (Year) Title. American Mineralogist, in press.

DOI: https://doi.org/10.2138/am-2020-7273

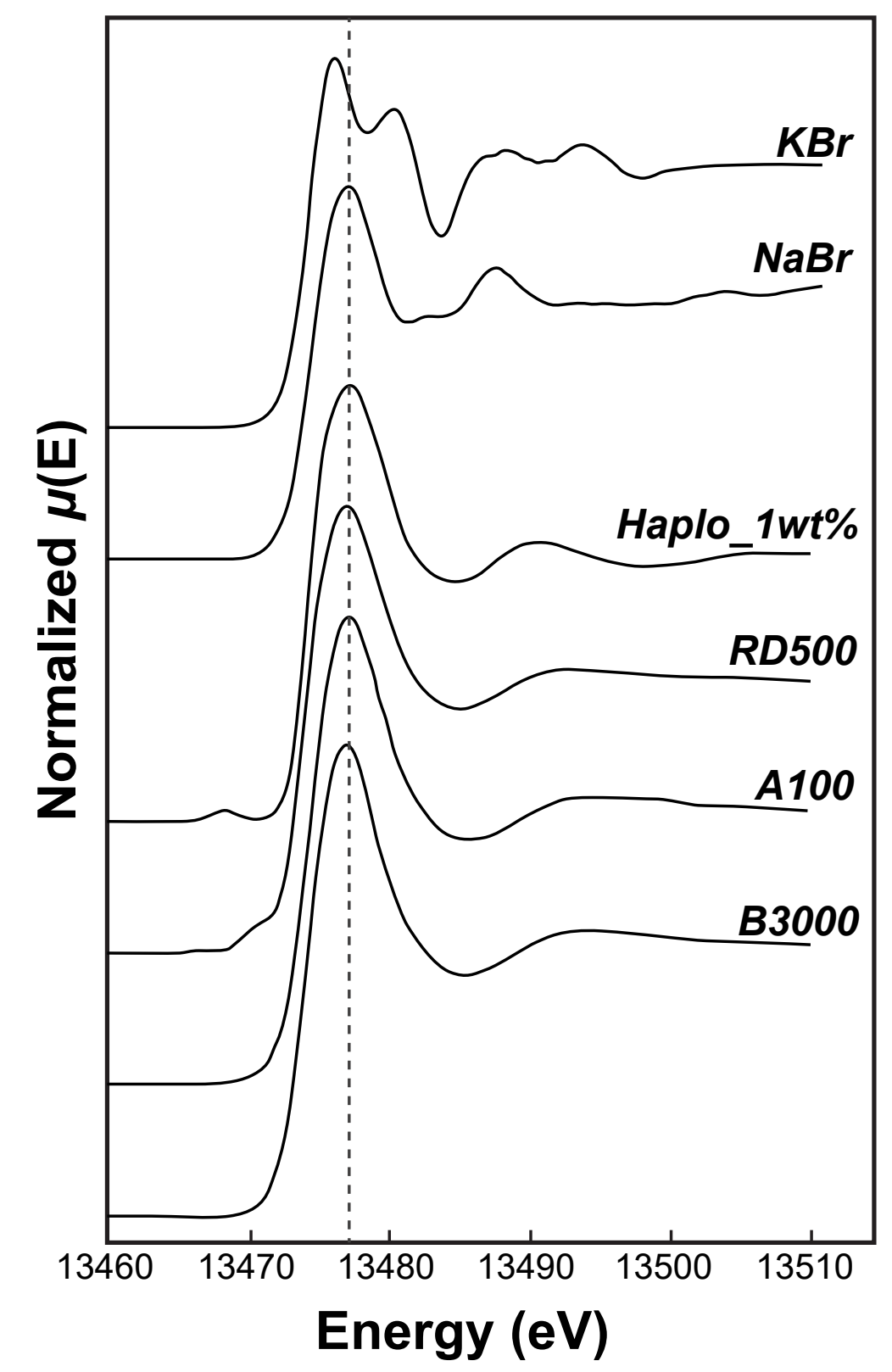

\section{Figure 2}

Always consult and cite the final, published document. See http:/www.minsocam.org or GeoscienceWorld 